\title{
A Revival Revived: Some Recent Primary Publications from the 'Naša niva' Period
}

\author{
BY
}

\section{ARNOLD McMILLIN}

The publication and republication of Byelorussian literary texts is always to be welcomed, nowhere more so than in the until relatively recently neglected area of early 20 th-century writing associated with the weekly newspaper Naša niva (1906-15). Indeed, one of the most serious weaknesses of post-Stalin Byelorussian literary criticism has been the unavailability of many of the works with which critics and literary historians have been concerned in their increasingly sophisticated studies. It is hard to know which is the sillier: to refer to works which are unavailable or, alternatively, to completely omit reference to major writers and works which, like Aleś Harun (18871920) and Harecki's novel Dźvie dušy (1919), to take two particularly scandalous examples, languish in unmerited obscurity for reasons entirely unconnected with literature. It can only be hoped that common sense may eventually prevail, and that these and other glaring omissions will be repaired, since they greatly distort the overall picture of Byelorussian literary development. However, even distortions of such magnitude should not obscure the genuine achievements of the last decade in publishing primarily texts from the Naša niva period, as the making available of the works of minor writers does much to lend body and substance to our view of a time which has hitherto been represented principally by such giants as Kupała, Kołas and Bahdanovič, whilst minor figures have, with the exception of Ciotka, remained unrepublished.

An important early survey incorporating the Naša niva period was L. M. Klejnbort's Molodaja Belorussija. Očerk sovremennoj belorusskoj literatury 1905-1928 $\mathrm{gg}$. (Minsk, 1928), and for English speaking readers a valuable outline appeared on the pages of this journal in the form of Alexander Nadson's 'Naša niva' (JBS, I, no. 3 (1967), pp. 184-206), but the beginning of a revival of Soviet interest in and recognition of this period was marked a decade ago by the publication of Sciapan Aleksandrovič's most valuable Puciaviny rodnaha stova (Minsk, 1971). Since then Aleksandrovič has edited and published a selection of the works of two popular writers of the period, Albiert Paŭłovič (Vybranaje, Minsk, 1975), and Karuś Kahaniec (Tvory, Minsk, 1979), as well as (in conjunction with V. S. Aleksandrovič) publishing an anthology of critical materials, the second half of which covers the Naša niva period (Bietaruskaja litaratura XIX-pačatku $X X$ st.: chrestamatyja krytyčnych materyjałaŭ, Minsk, 1978). Other 
primary publications include Hallaš Leŭčyk, Dola $i$ chleb, ed. Ja. Sałamievič and N. Laškievič, with an introduction by U. Kaleśnik (Minsk, 1980) and, most important of all, I. P. Cyhryn's selection of the prose, verse, and publicist writing of Jadvihin $S$. (Vybranyja tvory, Minsk, 1976).

Regrettably, in view of Aleksandrovič's pioneering work, the least satisfactory of these publications is in many ways the officially sponsored critical anthology where selectivity reduces the value of this collection of articles, reviews, and letters as a guide to the various trends and currents in the development of modern Byelorussian literature. From the Naša niva period, for example, the name of Vacłaŭ Eastoŭski (1883) is conspicuous by its absence. However distant Eastoŭski's political and national aspirations may be from official Soviet positions, his role in the national revival cannot be gainsaid, and there is no excuse for Aleksandrovič's publishing Janka Kupała's reply to Łastoŭski (Adzin z "parnaśnikaŭ", 'Camu płača pieśnia naša? [Adkaz Jurcy Vieraščaku]', Naša niva, 1913, no. 30, and Lavon Hmyrak's 'Jašče ab spłačvańni doŭhu', Naša niva, 1913, no. 33-4) whilst omitting (with only the crudest of tendentious summaries) the original article which provoked this important discussion on the nature and development of Byelorussian poetry (Jurka Vieraščaka [pen-name of Łastoŭski], 'Spłačvajcie doŭh', Naša niva, 1913, nos. 26-7). The significance of Łastoŭski's Karotkaja historyja Bielarusi (Vilna, 1910) for writers such as Alachnovič, Harun, Bahdanovič, and Kupała was clearly reflected in the dedication of the latter's lyric of 1910, Dudar, to "Vłast, the author of the "History of Byelorussia"' (a dedication which is consistently omitted from Soviet editions of his works), and Łastoŭski's own lively and entertaining tales (written under the penname 'Vłast') deserve reprinting if a full picture of the Naša niva period is to be given.

The publication of a selection of works by Jadvihin $\mathbf{S}$. (pen-name of Anton Lavicki, 1868-1922), another writer who failed to equate Marxist doctrine with his country's best interests, must be welcomed as a genuine step forward. I. P. Cyhryn's introduction is suitably circumspect, for, like Harun and many another nationalist who opposed early Soviet rule, Jadvihin $S$. was a nonconformist throughout his life, beginning with expulsion from the medical faculty of Moscow University during student disturbances in 1890 . The present collection, the first since Jadvihin S.'s death, incorporates both his Byelorussian and Russian works, the former of which include some excellent stories (or, as Bahdanovič saw them, prose fables), an extended poem Dzied Zavala (1910), and, historically if not artistically his most significant work, the unfinished novel Zołata (1920) which together with Ciška Hartny's Baćkava vola marks an early approach to what has become the leading genre of Soviet Byelorussian literature, the realistic novel. The volume also contains reminiscences, sketches, articles, and the celebrated translation of Garšin's Signal, concluding with two valuable documents relating to Jadvihin S.'s life: a biographical sketch by his daughter Vanda Lavickaja and a supplement to it by L. Vojcikava 
(pen-name of Ludvika Sivickaja, but better known as the Byelorussian writer Zośka Vieras, b. 1892). Stories like Z balničnaha žyćcia (1909), Padłasieńki (1910), Pavuk (1911), and Dačesnyja (1912) are still effective today, and well worth introducing to a new generation of readers, as are his good-humoured anecdotal tales.

Like Jadvihin S., Karuś Kahaniec (pen-name of Kazimir Kastravicki, 1868-1918) was an active nationalist who suffered for his convictions and who became established as a writer before the foundation of Naša niva (Jadvihin S.'s first original Byelorussian work was published in 1906). A man of parts who wrote prose fables, verse, and plays, as well as showing considerable talent as a graphic artist and sculptor (the volume is adorned with some of his charming sketches), Kahaniec was also a strong-minded individualist and his unwillingness to polish his works, or, more particularly, to change his own decidedly eccentric orthography, kept most of his works from the pages of Naša niva; indeed, he published relatively little during his lifetime. None the less, Bahdanovic in his major critical review of Byelorussian literature in 1910, Hłyby $i$ stai, declared Kahaniec's fables the best example of contemporary prose, and his witty comedy Modny šlachciuk (1910) remains with Kupała's Paŭlinka (1912) not only the first, but also one of the best of Byelorussian theatrical comedies. Although Kahaniec remained largely outside Naša niva, his stories are very typical of the period associated with that newspaper, both in their weaknesses such as over-reliance on plot or simply anecdotal elements, and in their strong social and patriotic concerns. Amongst the best are such atmospheric historical stories as Navasadskaje zamčyšča (1898) or Chalera 40-ha roku (1902), which anticipated the heroic view of Byelorussia's past canonized in Eastoŭski's History. Bahdanovič rightly noted a certain heaviness in much of Kahaniec's verse, best overcome in poems like Kobzar (1910) and Pieśnia zimie (1914) where his great feeling for the rhythms of folk verse and extensive knowledge of folklore were successfully assimilated into strong and original lyrics. In addition to Kahaniec's prose, verse and plays, Aleksandrovič publishes a selection of his rather interesting letters, which again reveal a man of wide interests and talents whose contribution to the Byelorussian national revival was no less significant for its distinctly individual character.

Neither Hallaš Leǔčyk (pen-name of Il'ja Laŭkovič, 1880-1944) nor Albiert Paŭłovič (1875-1952) were of the stature of Kahaniec or Jadvihin $S$., though both enjoyed a degree of popularity in the Naša niva period. Bahdanovič declared Leǔčyk talented, but insufficiently interested in developing his talent, and it is certainly true that he was one of the most consistent of early 20th-century Byelorussian poets, remaining within a narrow circle of melancholy themes - exemplifying, in fact, the 'weeping song' about which Eastoŭski, Kupała, and Hmyrak wrote. In addition to the well-known collection of verses Cyžyk biełaruski (1912), Leŭčyk's editors have published a selection of his other poetry, and Kaleśnik has provided a chatty, familiarly intimate introduction, befitting, perhaps, a secondary figure in the 
history of literature, but one who was very much a man of his time. In great contrast, Albiert Paŭłovič's popularity derived almost entirely from his broad good humour and lively satirical manner. Entering print on the pages of Naša niva in 1907, Paŭłovič quickly established himself as the leading comic poet of the day. Like Jadvihin S., he possessed a strong moralizing streak, and few of the social obsessions of the period. In addition to the comic verse for which he is mainly remembered, he also wrote a number of patriotic, nature, philosophical and religious lyrics, though in the latter genre he came nowhere near the achievement of Harun or, indeed, Kazimir Svajak (pen-name of Kanstancin Stapovič, 1890-1926), and Andrej Ziaziula (pen-name of Alaksandr Astramovič, 1878-1921) - the latter two also well worthy of republication.

Much remains to be done, and certain injustices continue to mar the overall publishing picture, but it is none the less good to see a more or less concerted attempt being made to re-establish the Naša niva period as one of great cultural stimulation and diversity, a revival in Byelorussia's spiritual fortunes that retains its interest and excitement more than half a century later.

\section{Authors of articles in Vol. V, No. 1}

L. A. J. HUGHES, Lecturer in the Department of Russian, University of Reading

A. B. McMillin, Bowes Professor of Russian and Head of the Department of Russian, University of Liverpool

A. NADSON, Rector of the Byelorussian Catholic Mission in England

J. OCHMANSKI, Professor and Director of the Department of the History of the Peoples of the USSR, Institute of History, University of Poznań

M. SIEKIERSKI, Research Fellow, University of California, Berkeley 